\title{
The Nature of a Dynamic Relationship between Audit Committee and Auditors, both Internal and External
}

\section{Al-Baidhani AM*}

The German University in Cairo (GUC) and Universiti Putra Malaysia, Malaysia

\begin{abstract}
Good corporate governance is now considered a basic condition to accept and register an organization in most of the Stock Exchange Markets all over the world. The audit committee plays a major role in corporate governance regarding the organization's direction, control, and accountability; part of which is the organization's internal control which is used to provide reasonable assurance about the integrity of management and reliability of the financial reporting. This paper focuses on the audit committee's powers and functions. The importance of the audit committee's oversight and monitoring responsibilities to the organizations' board of directors, shareholders, and other stakeholders, as well as to governing and regulating bodies, have been increasing, especially after the corporate collapse and the passage of the U.S. Sarbanes-Oxley Act of 2002. Consequently, most publicly held companies all over the world have been asked to establish and maintain audit committees. These companies and other types of organizations do establish and maintain audit committees to oversee and monitor their overall financial performance, including overseeing the preparation of the financial statements and other financial reports, as well as monitoring the external and internal auditors' performance. The relationship between the audit committee and both external and internal auditors is important for all parties to fulfill their job commitments. An organization's board of directors relies on the audit committee's reports about matters related to managing, directing and controlling the organization. The audit committee acts as a link, and facilitates the communications, between the board of directors and both internal and external auditors.
\end{abstract}

Keywords: Audit committee; Internal auditors; External auditors; Corporate governance; Internal control

\section{Introduction}

The concept of audit committee was first introduced in 1939 by the New York Stock Exchange (NYSE) [1]. In 1972, the U.S. Securities and Exchange Commission (SEC) was the first to recommend that public companies should create audit committees comprised of directors from outside the relevant companies' managements. In its Statements on Auditing Standards (SAS) 61 of 1988, the American Institute of Certified Public Accountants (AICPA) [2,3] issued "Communication with Audit Committees" regarding the relationship between the audit committee, external auditors, and management of public companies. In 1999, The Blue Ribbon Committee (BRC) [4] recommended major rule changes, related to improving the effectiveness of the corporate audit committee. And later, after the corporate collapse of Enron, WorldCom, et al. the Sarbanes-Oxley Act was passed by the U.S. Congress in 2002 giving more power to audit committees, especially in regard to whistleblower and disclosure requirements [5].

The audit committee is operating as a representative of the board of directors in regard to overseeing and monitoring the organization's financial reporting, disclosure, audit and control activities; this applies to public, private, and mix sectors. The audit committee usually helps the board of directors to ensure that the organization complies with relevant regulations and ethical standards, to ensure that the internal auditors are independent and competent, to make sure that the financial statements have been prepared correctly and accurately, and that the compensations paid to the organization's executives were according to fairness and professionalism [6-8]. As part of improving the integrity of the organization's financial information, a regulatory body may require a public company to create an independent audit committee.

\section{Audit Committee's Basic Functions}

\section{Composition}

Although it is compulsory in some countries that all publicly held companies should have audit committees, many non-public companies have audit committees voluntarily established for better oversight and monitoring of these companies' financial and accounting performance [9]. Usually the audit committee should be composed of three to six members. The European Union requires that there should be an audit committee for each publicly held company; however, each member state has the power to decide on the composition of these committees (i.e., members from outside the company, from its supervisory body, and/or members appointed by the company's shareholders). The Union also requires that at least one member should be independent of the company and competent (have expertise in accounting and/ or auditing) to enhance the effectiveness of the audit committee's oversight and monitoring activities. On the other side of the Atlantic, the United States requires that the public companies should have audit committees composed of independent members from outside the companies' managements, and that there should be at least one financial/accounting expert.

Since it is critical for the audit committee to be independent, the NYSE requires that at least three audit committee members should be independent and have no relation with the company. Similarly, the SEC issued rules to exclude any member who is not independent (i.e., who was or still working for the company during the last three years, who

*Corresponding author: Al-Baidhani AM, The German University in Cairo (GUC) and Universiti Putra Malaysia, Malaysia, Tel: 60 1-800-22-5587; E-mail: baidhani@yahoo.com

Received June 15, 2016; Accepted October 22, 2016; Published October 31, 2016

Citation: Al-Baidhani AM (2016) The Nature of a Dynamic Relationship between Audit Committee and Auditors, both Internal and External. Bus Eco J 7: 262. doi: 10.4172/2151-6219.1000262

Copyright: (c) 2016 Al-Baidhani AM. This is an open-access article distributed under the terms of the Creative Commons Attribution License, which permits unrestricted use, distribution, and reproduction in any medium, provided the original author and source are credited. 
receives compensation for participating in other committees which have links with the audit committee [10-13], or who is a family member of one of the company's executives). In addition to independence, competency is also taken into consideration as regards the composition of audit committee members. Consequently, the BRC recommended that the audit committee should be composed of members who understand the organizations' financial statements, and recommended that at least one member should be expert in finance or accounting field in order to have an audit committee capable of performing its oversight and monitoring activities to the fullest extent [14].

\section{Meetings}

Audit committee meetings have a major impact on the evaluation of the organization's overall performance and its internal control functions. Consequently, we will be looking at three features of such meetings, as follows:

Frequency: Even though it is very important for the audit committee meetings to be frequent, it is noted that most of the organizations do not meet frequently [15]. Many committees meet on a monthly basis, while others meet on a quarterly basis or even a semi-annual basis. According to the American Bar Association codes of 1978, the minimum number of meetings is twice a year but this number has been increased to four times a year according to the BRC codes of 1999 [4]. In Europe, the codes are silent on this issue; however some European States, such as the United Kingdom and the Czech Republic, recommended that these meetings are to be 3-4 times per year. The frequency and duration of these meetings have to be according to the size of the organization and the number and size of issues to be discussed during such meetings. Consequently, while four times a year could be too much for some organizations, twelve times a year could be just sufficient for others. However, what is more important than the frequency of the meetings is the content and results of such meetings [16].

Attendance: In addition to the less-frequent meetings held by many audit committees, it is noticeable that not all of the members attend these meetings. However, the attendees should not be limited to the committee members. The audit committees invite CEOs, internal auditors, external auditors, regulatory bodies, finance directors, and relevant others, to attend such meetings, with whom the committee members discuss issues related to the organization.

Content: There should be an agenda for the meeting summarizing the issues that would be discussed including, among other things, current internal and external auditors' reports, the organization's accounts (including funds, revenues, and expenses), assessment of the internal audit programs, and review of the management's responsiveness to the notes made by the external and internal auditors [17]. The organization's compliance with the laws, regulations, and standards should also be discussed during these meetings. The minutes of the meetings should be noted by a specified person describing the issues that have been discussed, the results the attendees reached to, and the relevant decisions that have been made.

\section{Activities and Responsibilities}

Often the respective organization has "terms of reference" which shows clearly the activities and responsibilities of the audit committee. The board of directors and its committees (including the audit committee) rely on the organization's management to run the daily operations. The audit committee activities and responsibilities are to oversee and monitor the organization's overall financial performance, especially the preparation of its financial statements (balance sheet, income statement, statement of stockholders equity, etc.), managerial financial reports such as cost and budgeting reports, the effectiveness and efficiency of the organization's internal control, and the performance of both internal and external auditors. European Union Directive 2006/43/EC states that "the audit committee shall (a) Monitor the financial reporting process; (b) Monitor the effectiveness of the company's internal control, internal audit where applicable, and risk management systems; (c) Monitor the statutory audit of the annual and consolidated accounts; (d) Review and monitor the independence of the statutory auditor or audit firm, and in particular the provision of additional services to the audited entity [18]".

The audit committee plays a major role in selecting the external auditors since it nominates them, asks them to submit their proposals regarding the audit process, then it recommends to the organization's board of directors whom it sees are the best to perform the external audit. Additionally, the audit committee participates fully in determining the fees that would be paid to the external auditors. Appointing or terminating the head of the internal audit department, or at least issuing relevant recommendations, is also part of the committee activities.

The committee is also responsible for ensuring that the organization complies with the relevant local and international laws, implementing regulations and ethical standards; as well as complying with the organization's bylaws and internal guidelines [19]. Internal and external auditors' reports are to be reviewed by the committee so that the committee members discuss such reports with the concerned parties, and make sure that the valid notes are taken into consideration and executed by the management. The scope of the internal and external audit functions are also determined by the audit committee. Further details about the relationship between the audit committee and both external and internal auditors are stated hereunder; I also mention hereunder the important roles that the committee plays in regard to corporate governance and the organization's internal control.

The audit committee reviews the organization's annual, quarterly, and monthly reports; it issues its reports and recommendations to the board of directors; and annually issues a report submitted to the shareholders (as part of the organization's annual report) describing its activities and responsibilities during the year [20-24].

\section{Audit Committee's Relationships}

The audit committee has relationships with almost all of the organization's stakeholders (e.g., board of directors, management, internal auditors, external auditors, and, to a certain extent, shareholders and financial statement users), as well as the governing and regulatory bodies. However, in this section of the paper, I would focus only on its relationships with internal auditors and external auditors [25].

\section{Relationships with internal auditors}

Listing all the tasks of the internal auditors is beyond the scope of this paper. However, I would refer to the tasks that are directly related to the audit committee activities as follows: after the U.S. corporate scandals and the collapse of Enron and WorldCom, as well as Arthur Andersen and others, the internal audit tasks have been changed, especially pursuant to the issuance of Sarbanes-Oxley Act passed by U.S. Congress in 2002. One of the main responsibilities of the audit committee is to enhance and maintain the internal auditors' independence in order to enable them to achieve their duties.

The relationship between the audit committee and the internal auditors is important for both parties to fulfill their job commitments 
[26]. The internal auditors provide the committee with the necessary information to which they have direct access, same as the organization's management, in order to enable the audit committee to accomplish its oversight and monitoring mission. On the other hand, the audit committee supports the position of the internal audit function and submits management's irregularities and other relevant managerial and financial issues to the board of directors, after discussing such issues with the internal auditors and relevant other parties.

The audit committee is concerned with recruiting and terminating the head of the internal audit, and the frequency and duration of the meetings with the internal auditors [27-29], as well as ensuring that the internal auditors, especially their head, can communicate directly with the audit committee anytime. The audit committee's meetings with the head of the internal audit enhance the independence of the internal audit function, supporting the parties' discussion about management's errors, irregularities, violations, and fraud.

Whereas the oversight of financial reporting and the monitoring of the internal audit performance are two of the main activities of the audit committee, it is mandatory that the audit committee members, or at least one of them, should have the financial or accounting expertise in order to understand the technical and control issues related to the internal audit to enable the audit committee to review the internal auditors activities and the results they reach to. Consequently, independence and financial expertise are very critical for the audit committee to play its important role and take advantage of the internal auditors' performance. Whenever there are problems or obstacles, the audit committee performs the necessary investigations using internal feedback, its expertise, and external consultations if needed. Evaluation of the organization's internal control structure and process should also be one of the audit committee's basic functions [30]. The audit committee also evaluates the internal auditors' effectiveness, their plans and work arrangements, as well as the resources allocated to them. Additionally, the internal auditors should be involved in issues related to the organization's joint ventures, environmental matters, and international operations. Two important related issues (i.e., corporate governance and internal control) are discussed in detail hereinafter.

\section{Relationships with external auditors}

Likewise, listing all the tasks of the external auditors is beyond the scope of this paper. However, I would refer to the tasks that are directly related to the audit committee activities as follows: as stated above, the audit committee nominates and assists in selecting the external auditors (also called certified public accountants "CPAs", chartered accountants "CAs") to audit and/or review the organization's accounts and issuing their opinion about the correctness and accuracy of the organization's financial statements, and that they present fairly the financial position of the organization. Changing the external auditors also requires direct interference by the audit committee. In order to protect and preserve the shareholders' interests, the audit committee oversees the nature and scope of work of the external auditors, evaluates their effectiveness, and recommends the proper audit fees that should be paid to them. The audit committee assists in ensuring that the external auditors are independent, and that there is no conflict of interest which may weaken the external auditors' ability of issuing their opinion about the organization's financial statements and financial position [31].

The external auditors submit their reports to the audit committee where both parties discuss important issues, such as management's errors, irregularities, and fraud; problems or obstacles in the internal control process; and problems related to the preparation of financial statement or financial reporting. The AICPA requires that external auditors communicate with the audit committee formally as a main part of the audit performance [32]. AICPA's (SAS 61) of 1981 requires that the audit committee receives additional information from the external auditors that may help it in the oversight of the financial reporting and disclosure process. The AICPA also requires that the external auditors communicate with the audit committee regarding errors and irregularities (SAS 53), illegal acts by clients (SAS 54), and internal control structure (SAS 60).

The audit committee reviews the external auditors' management letter and submits its relevant notes to the board of directors. The committee also reviews the external auditors' plans and arrangements of works, and may ask the external auditors to report to it about any differences or disputes between them and the organization's management. The audit committee also facilitates the communications between the external auditors and the organization's board of directors and attends their relevant meetings. Additionally for independence purposes [33], the audit committee may review any non-audit service agreements with the external auditors to understand the nature and magnitude of relevant fees paid.

\section{Audit Committee's Roles}

Even though the audit committee plays many important roles, most of which have been referred to hereinabove, I state hereunder two of them in details:

\section{Roles in corporate governance}

Corporate governance "is the system by which companies are directed and controlled" [5]. It includes relationships between, and accountability of, the organization's stakeholders, as well as the laws, policies, procedures, practices, standards, and principles which may affect the organization's direction and control. Most, if not all, of the aforementioned audit committee activities and relationships are related directly or indirectly to the audit committee roles in corporate governance [34]. Additionally, corporate governance includes reviewing the organization's practices and policies as regards the ethical standards and principles, as well as the organization's compliance with its own code of conduct. The audit committee's composition, competence, independence, and expertise, as per above details, are strongly correlated to the corporate governance.

The increasing demand on the corporate governance and accountability related to the board of directors, particularly the recent lawsuits and investigations made the creation of audit committees an extremely necessary step. The big four CPA firms, Price Waterhouse Coopers [6-8], Deloitte, Ernst \& Young, and KPMG [7-9], as well as the Committee of Sponsoring Organizations (COSO) recommended certain oversight practices for audit committees to follow, providing guidelines about the audit responsibility in evaluating and strengthening corporate controls.

The SEC confirmed its interest in audit committees by: “(a) urging registrants to form audit committees comprised of outside directors; (b) requiring all publicly held companies' proxies to disclose information about the existence and composition of their audit committees; and (c) requiring publicly held companies to state the number of audit committee meetings held annually and to describe their audit committees' function [35]".

As part of the corporate governance mechanism, the audit committee oversees the organization's management, internal and 
external auditors to protect and preserve the shareholders' equity and interests; however, the audit committee's nature and scope of work should be reviewed to make sure that it is capable of playing its role in this regard appropriately, especially after being recently criticized for its shortcomings in achieving the corporate governance objectives [36].

In 1987, the National Committee on Fraudulent Financial Reporting (the Treadway Commission) was created to identify factors that can lead to fraudulent financial reporting and recommend procedures to reduce fraud incidences. The 1987 Treadway report identified audit committees as effective means for corporate governance and suggested a list of objectives for audit committees to consider. Among the numerous recommendations detailed in the report, the Commission stated that audit committees should be informed, vigilant, and effective overseers of the financial reporting process and the company's internal controls.

In order to improve the oversight responsibility related to the audit committee, board of directors, management, internal auditors, and external auditors, in 1999 the BRC referred to the role of the corporate governance, suggesting that the audit committee report should be included annually in the organization's proxy statement, stating whether the audit committee has reviewed and discussed the financial statements with the management and the internal auditors. As a corporate governance monitor, the audit committee should provide the public with correct, accurate, complete, and reliable information, and it should not leave a gap for predictions or uninformed expectations.

It is very important to determine and understand the audit committee's oversight and monitoring functions in order to establish and improve the credibility and trustworthiness of the audit committee as a corporate governance mechanism [37]. Sarbanes-Oxley Act of 2002 which was passed mainly to protect the investors has a big impact on the corporate governance and accountability, as well as on corporate disclosure. In order to be accepted in most of the Stock Exchange Markets, an organization should have good corporate governance.

As part of the corporate governance, the audit committee should also examine the non-audit services, referred to above; Arthur Andersen, for instance, as Enron's external auditors, was paid US\$27 million for non-audit services, in addition to the US\$25 million for auditing services, which created conflict of interest and affected the auditors' independence negatively. It is expected that the audit committees will play a broader corporate governance role in the future, and that the main parties in the governance field support them strongly; however, observers see that there should be a clear and written statements showing the audit committees' activities, responsibilities, objectives, and composition.

\section{Roles in internal control}

Internal control, defined by COSO, as "process affected by entity's board of directors, management, and other personnel, designed to provide reasonable assurance regarding the achievement of objectives in the following categories: a) Effectiveness and efficiency of operations; b)Reliability of financial reporting; and c)compliance with laws and regulations". Even though it is well-known that the internal control structure cannot prevent or detect all errors and irregularities, organizations establish and maintain such structure for the purpose of providing reasonable, not absolute, assurance regarding the integrity of management, as well as the accuracy and reliability of financial reporting. Internal control structure includes policies, procedures, and practices followed by the organization to control its operations, particularly its financial part, and to ensure the organization's compliance with the valid and relevant laws and regulations, as well as the organization's own bylaws and resolutions.

The audit committee receives reports about the internal control's effectiveness and efficiency from the organization's management, internal and external auditors [35]. The committee has full authority to investigate about any issues which may affect the organization's internal control and financial reporting. It should have access to all relevant information, and access to resources which may enable it to perform such investigations appropriately. The committee meets with the management, internal and external auditors to discuss issues related to internal control anytime it deems necessary. It also submit reports to the board of directors about the results it reaches to, as well as recommendations regarding the improvement of the internal control process and how to maintain an effective and efficient internal control system [33].

Evaluation of the internal control structure and process is considered one of the most, if not the most, important oversight responsibility faced by the audit committee. This importance of internal control has also been indicated in COSO; Braiotta; Price Waterhouse [6]; and Treadway Commission [17]. The audit committee receives enquiries from the board of directors, shareholders, and financial statement users about the effectiveness and efficiency of the organization's internal controls in order to know whether there are material illegal acts, irregularities, errors, or unethical activities. The committee assists the external and internal auditors in reporting internal control's major deficiencies to the board of directors or other governing body of the organization; and also improves the communications between these parties. In order to improve the internal control structure and process, the audit committee monitors and oversees the organization's financial and operational controls, as well as the organization's compliance with these controls.

\section{Summary and Conclusion}

This paper focuses on the audit committee's powers and functions. The importance of the audit committee's oversight and monitoring responsibilities to the organizations' board of directors, shareholders, and other stakeholders, as well as to governing and regulating bodies, have been increasing, especially after the corporate collapse and the passage of the U.S. Sarbanes-Oxley Act of 2002. Consequently, most publicly held companies all over the world have been asked to establish and maintain audit committees. These companies and other types of organizations do establish and maintain audit committees to oversee and monitor their overall financial performance, including overseeing the preparation of the financial statements and other financial reports, as well as monitoring the external and internal auditors' performance. The relationship between the audit committee and both external and internal auditors is important for all parties to fulfill their job commitments. An organization's board of directors relies on the audit committee's reports about matters related to managing, directing and controlling the organization. The audit committee acts as a link, and facilitates the communications, between the board of directors and both internal and external auditors. The audit committee plays a major role in corporate governance regarding the organization's direction, control, and accountability; and also plays an important role regarding the organization's internal control to provide reasonable assurance about the integrity of management and reliability of the financial reporting. Good corporate governance is now considered a basic condition to accept and register an organization in most of the Stock Exchange Markets all over the world. 
Citation: Al-Baidhani AM (2016) The Nature of a Dynamic Relationship between Audit Committee and Auditors, both Internal and External. Bus Eco J 7: 262. doi: 10.4172/2151-6219.1000262

Page 5 of 5

\section{References}

1. New York Stock Exchange (2002) NYSE Issues Sweeping Proposals to Reform Corporate Governance and Require Disclosures in Connection with Revisions to Its Listing Standards, New York.

2. American Institute of Certified Public Accountants (AICPA) (1993) In the public interest: a special report by the public oversight board of the SEC practice section, AICPA.

3. American Institute of Certified Public Accountants (AICPA) (1995) Directors, management, and auditors - allies in protecting shareholder interests, $\mathrm{POB}$, AICPA

4. Blue Ribbon Committee (BRC) (1999) Improving the effectiveness of corporate audit committee, New York, NY, USA.

5. Cadbury Committee (1992) Report of the Committee on Financial Aspects of Corporate Governance Including Code of Best Practice, London.

6. Price Waterhouse Coopers (1999) Audit Committees: Good Practices for Meeting Market Expectations, Price Waterhouse Coopers pp: 7-9.

7. Coopers \& Lybrand (1995) Audit Committee Guide, New York.

8. Ernst and Young (1990) A new focus for the audit committee, Ernst and Young, Toronto.

9. KPMG (2001) Corporate Governance Trends in Europe, Audit Committee Institute.

10. Abbot JL, Parker S, Peters GF (2002) The Effectiveness of Blue Ribbon Committee Recommendations in Mitigating Financial Misstatements: an Empirical Study.

11. Abdolmohamaadi MJ, Levy ES (1992) Audit committee members perceptions of their Responsibility, Internal Auditing, Summer pp: 53-63.

12. Archambeault D, Dezoort FT (2001) Auditor opinion shopping and the audit committee: an analysis of suspicious auditor switches. International Journal of Auditing 5: 33-52.

13. Beasley MS, Carmichael DR (1998) Boards of directors and fraud. CPA Journal 68: $56-58$.

14. Burke FM, Guy DM (2001) Audit Committees: A Guide for Directors, Aspen Law \& Business, New York.

15. Bradbury ME (1990) The incentives for voluntary audit committee formation. Journal of Accounting \& Public Policy 9: 19-36.

16. Carcello JV, Neal TL (2000) Audit committee composition and auditor reporting. The Accounting Review 75: 453-467.

17. The Committee of Sponsoring Organizations (1992) Internal control - integrated framework, The National Commission of Fraudulent Financial Reporting the (Treadway Commission), USA.

18. DeZoort FT (1997) An investigation of audit committees oversight responsibilities. ABACUS 33: 208-227.

19. DeZoort FT, Hermanson DR, Archambeault DS, Reed SA (2002) Audit committee Effectiveness: a synthesis of the empirical audit committee literature. Journal of Accounting Literature 21: 38-75.
20. Eichenseher JW, Shield D (1985) Corporate director liability and monitoring preferences.

21. Federal Reserve System (1991) Federal Deposit Insurance Corporation Improvement Act.

22. Audit committees: legislation needed to strengthen bank oversight (1991) Report to Congressional Committee. General Accounting Office.

23. Green DL (1994) Canadian audit committees and their contribution to corporate governance. Journal of International Accounting Auditing and Taxation 3: 1-5.

24. Independent Standard Board (1999) Independence standard No 1 : Independence Discussion with Audit Committees. Journal of International Accounting \& Auditing 3: 135-151.

25. Kalbers LP, Fogarty TJ (1993) Audit committee effectiveness: an empirical investigation of the contribution of power. Auditing: A Journal of Practice \& Theory 12: 24-49.

26. Menon K, Williams D (1994) The use of audit committees for monitoring Journal of Accounting \& Public Policy 13: 121-139.

27. McDonald Commission (1988) Report of the Commission to Study the Public Expectations of Audits. Canadian Institute of Chartered Accountants.

28. Maijoor S (2000) The internal control explosion. International Journal of Auditing 4: 101-110.

29. McMullen DA (1996) Audit committee performance: an investigation of the consequences associated with audit committees, auditing. Journal of Practice and Theory 15: 87-103.

30. NACD Blue Ribbon Commission on Audit Committees (2004) Report of the NACD Blue Ribbon Commission on Audit Committee: A Practical Guide . National Association of Corporate Directors.

31. Porter BA, Gendall PJ (1998) Audit Committees in Private and Public Sector Corporates: an Empirical Investigation. International Journal of Auditing 2: 49-69.

32. Sarbanes P, Oxley M (2002) Sarbanes-Oxley Act of 2002. US Congress, Washington.

33. Scarbrough DP, Dasaratha VR, Raghunandan K (1998) Audit committee composition and interaction with internal auditing: Canadian evidence. Accounting Horizon 12: 51-62.

34. Thornton G (1997) The Expected Role of Audit Committee, Grant Thornton, New York.

35. Report of the National Commission on Fraudulent Financial Reporting, Washington (1987) Treadway Commission.

36. Turley S, Zaman M (1999) The Effects of Audit Committees on Corporate Accountability and Governance, Working Paper, University of Manchester, Manchester.

37. Zaman M (2000) Operation, power and effects of audit committees: evidence from case study of Assurance Ltd. 6th Interdisciplinary Perspectives in Accounting, 7-12 July, Manchester. 